\title{
第75回日本循環器学会学術集会
}

\section{1. 虚血性心臟病診療における画像診断の進歩}

\section{血管内イメージングからみた プラーク破綻のメカニズム}

日本大学医学部内科学系循環器内科学分野廣驾高

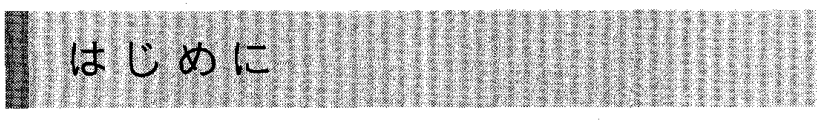

急性冠症候群 (acute coronary syndrome: ACS) の主病態は, プラークの破綻とそれに引き続く血 栓形成とされる.しかし，ACSの発症の原因はプ ラークの破綻だけではないこと，またプラークが 破綻しても必ずしもACS 溌症しないことが示 されている，ただ，プラークの破綻は依然として $\mathrm{ACS}$ 主病態であることには恋わりなく，その メカニズムを知ることは重要なことと思われる. 当初プラークの破綻は, 病理学標本から単にプ ラーク表層の線維性被膜の破裂や断裂によるもの とされていた。しかし，血管内イメージングの登 場により, 生体で直接プラークの破綻が観察でき る時代が到来し，破綻は思った以上にかなり複雑 な病態を呈していることが示唆されつつある. 本 稿では，プラーク破綻のメカニズムについて，と くに血管内イメージングを用いて得られた知見か ら考察する。

\section{vulnerable plaque $\measuredangle 415$-群 $)$ 存在}

$\mathrm{ACS}$ を発症しやすいプラークの一群があると の認識が広まり，この用語が生まれた。ただ, vulnerable plaque の定義には，プラーク表面が 破裂しやすいプラークという狭い定義と, ACS を発症しやすいプラークという広い定義がある.
この狭い定義は，広い定義にそのまま包含される わけではない. ACS 患者の冠動脈には, 責任病 変以外にも複数のプラーク破綻がしばしば観察さ れる1).それらは責任部位と同時に破綻したわけ ではなく, より以前に破綻し, しかし心血管イべ ント発生につながらなかつた silentなものである と考えられている.つまり，プラークは破綻した が，ACSの発症にはいたらなかったものがある ことを示す.

一方, プラークの破綻以外にも ACSには種々 の原因が示唆されている. Naghavi, Libby, Virmani らを含む多くの研究者により，「ACSを 発症しやすいプラーク」を列挙し, vulnerable plaque の定義づけや分類が試みられた2). それに よれば，易破裂性（もしくはすでに破裂した）プ ラークだけでなく, プラーク表面にびらんを起こ したプラークと起こしそうなプラーク，プラーク 内出血, 結節状石灰化を有するプラーク, 高度狭 窄病変からの移行があげられている.

また破裂しやすいプラークだけに限定したとし ても，その病理学的特徴も画一的ではない。破綻 しゃすいプラークの組織学的特徵には, (1)薄い 線維性被膜や大きな脂質コアを有する偏心性プ ラーク, (2)炎症細胞, マクロファージの集簇, (3) 陽性リモデリングの存在, (4) spotty な石灰化の 存在などがあげられている.つまり, vulnerable plaque というのは, 決して単一の特徵をもったプ 


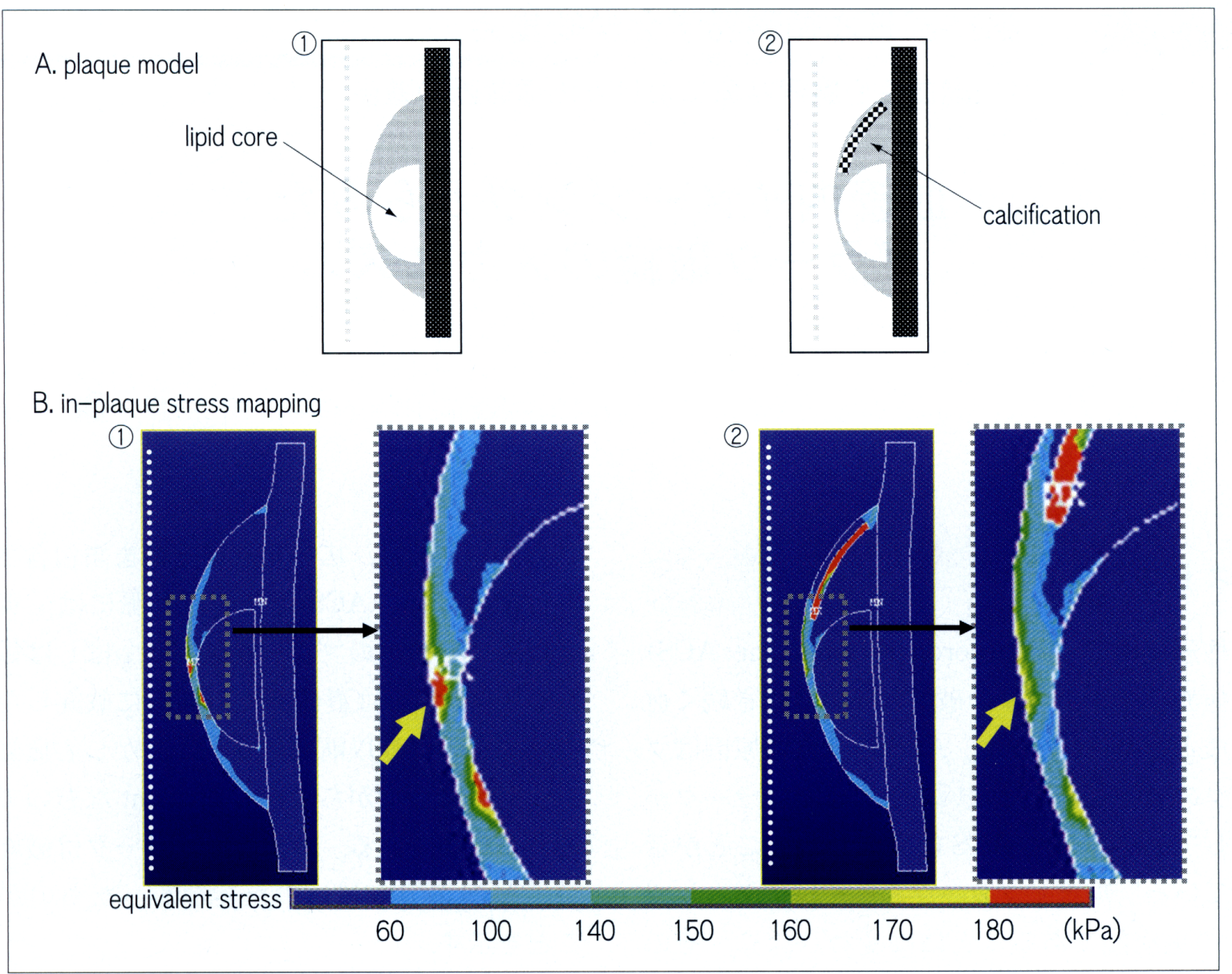

図 1 線維性被膜に加わる局所ストレス値と表在性石灰化の関係（実例）

脂質コアを覆う線維性被膜にはストレスが集中しやすいが (左下図 : 赤色の部分), 近くに石灰化があるとそ の值が緩和されていることが示されている.

(文献 4 より引用)

ラークではないのである.

さらに，たとえば線維性被膜の厚さが60 $\mu \mathrm{m}$ で 脂質コアの厚さが $100 \mu \mathrm{m}$ のプラークと，それぞ れが $100 \mu \mathrm{m}, 300 \mu \mathrm{m}$ のプラークとでは, どちら がぞれだけ定量的に vulnerability（易破綻性）が 大きいのかを定量表現することはいまだできな い. 総合的に判断して vulnerability を一つの連 続的数值指標で示す方法はまだないのである.

\section{vulnerable plaque の組織性状}

\section{1. 線維性被膜の菲薄化}

線維性被膜の菲薄化は確かに ACS を発症する もつとも重要な要因である ${ }^{3)}$. 病理学的検討によ れば，線維性被膜は65 $\mu \mathrm{m}$ 以下に菲薄化すると破
裂しやすいと報告されている，しかし，筆者らの 検討によれば，線維性被膜にかかる引つ張り応力 は，線維性被膜が菲薄化すればするほど確かに 急激に増加するが，同じ厚さの線維性被膜であつ ても周りの組織（とくに石灰化）の空間的配置に よってその応力が容易に減弱することがあること が判明している4) (図 1，2)。すなわち, 線維性被 膜の厚さだけをもって，プラークの vulnerability をそのまま表しているとは限らないのである，石 灰化の程度だけでなく，脂質コアの大きさなど や，プラーク全体の体積や形状も考慮に入れなけ ればならないのである.

Tanaka らは, optical coherence tomography (OCT) を用いた研究により ACS を発症したプ ラークの残存線維性被膜の厚さが運動時に発症し 


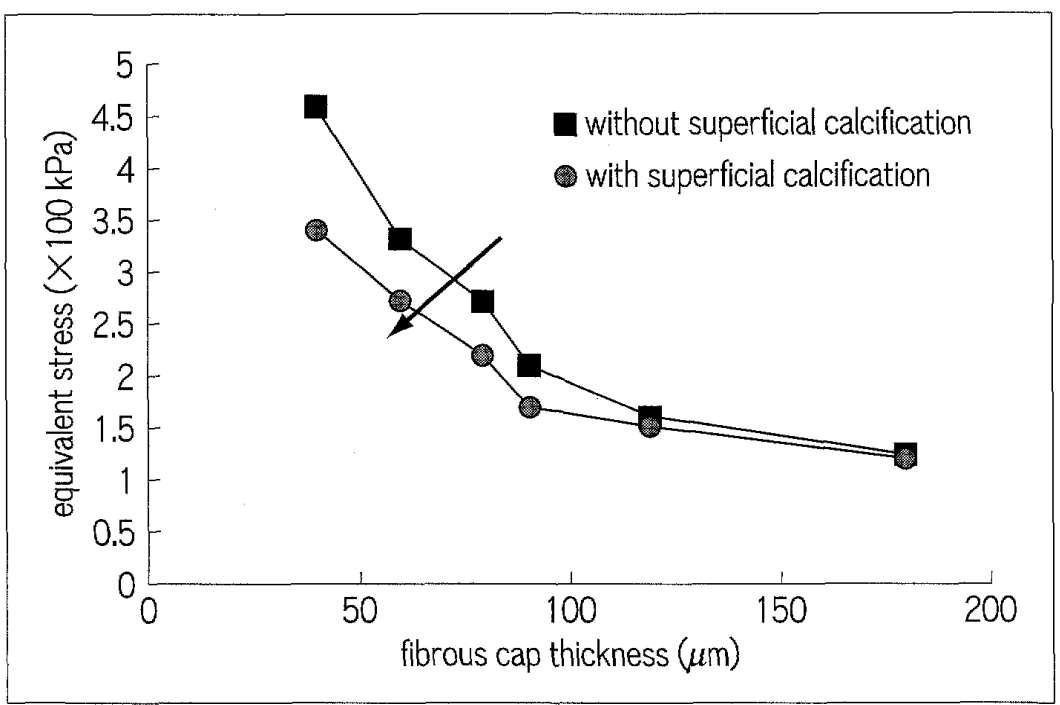

図 2 線維性被膜に加わる局所ストレス值と表在性石灰化の関係（グラ フ表示)

横軸が線維性被膜厚, 縦軸が equivalent stress 值（種々の力问の引つ張り応 力を合成して $1 つ の$ 值としたもの）を示す，近傍の表在性石灰化の有無によ り異なることを示す，表在性石灰化がない場合，線維性被膜厚が薄くなるほ ぞストレス值は上昇する．とくに $65 \mu \mathrm{m}$ 以下となると急激に増し，線維性被 膜が破断する経験的闇値とされる $300 \mathrm{kPa}$ を超える. しかし，表在性石灰化 が近傍にあると，この曲線の傾きが左下方向に移動する，同じ被膜厚であっ ても，同じストレスが加わるとは限らないことがわかる．(文献 4 より引用)

たものほど厚いこと（しかも65 $\mu \mathrm{m}$ 以上であるこ と）を報告した5)。一定の薄さが必要であるとは 限らないわけである.

そこで，筆者らは三次元血管内エコー法を用い て，近くの石灰化の分布情報をインプットし，関 心部位のプラーク表面において, 線維性被膜が破 れはじめるとされる経験的応力值（約 $300 \mathrm{kPa})$ となるために，ぞれだけ線維性被膜がそこで薄 くならなければならないか，すなわち critical fibrous cap thickness (臨界厚) を求め, その部位 で直接測定した線維性被膜厚とそれを比較して, 不安定性を評価することを提唱している4).

また，仮に同じ厚さのものであっても，同じ時 期に一斉に破裂するわけではない.Asakuraら は，血管内視鏡を用いた研究により，線維性被膜 の菲薄化した脂質コアの発達したプラークと思わ れる黄色プラークが, ACS の責任病変だけでな く, 非責任病変や非責任枝にも同時に多く観察さ れると報告した6).すなわち，vulnerable plaque があちこちで時を違えて破裂し，間がわるく大き
な血栓を生じたとき ACS として発症するのでは ないかと考察をしている.

\section{2. マクロファージの集積}

マクロファージが集積することにより，蛋白分 解醳素が分泌され，線維性被膜が脆弱化すること が示唆されている. マクロファージは，プラーク 内の引つ張り応力が増しているところ7)や，血流 から受けるプラーク表面にかかるずり応力 (shear stress）が局所集中しているところ采まりや集まり すいとされている，現にプラークにおけるプラー ク内応力が集中しているところにプラーク破綻が 多いことが報告されている.

プラークの破緃は，プラークの肩領域に多い $(50 \sim 70 \%)^{9)}$ とされるが，偏心性プラークの真ん 中から破裂している例も散見される $(<40 \%)^{10)}$. その理由としてプラークの破綻は圭力集中だけで なく，上記のような炎症細胞浸潤の場所も関与し ていることが考えられている. 


\section{3. プラークのびらん}

$\mathrm{ACS}$ の発症はプラークの破裂だけでなく，プ ラーク表面のびらんによっても起こることが報告 された. プラークのびらんは，冠動脈内血栓症の $1 / 3$ にみられるとの報告もあるほど，血栓形成に かなり関与しているようである．生体での血管イ メージング技術ではこのびらんを正確に描出でき ないため, ACS 発症にぎれだけどのように関与 しているかについては不明な点も多い.

\section{4. 石灰 化}

前述のように，表面の大きな石灰化は，近傍の プラークの引つ張り応力を減弱させ，プラークを より安定化させる方向に働いているようである. しかし，Eharaらは，血管内エコー法（IVUS） による観察により，プラークの spotty calcificationが ACS 患者に多く見受けられることを報告 している11).Virmani らは，結節様石灰化は，そ れ自体が崩壊し，血栓を誘発するとの考察をして いる12).さらにVengrenyuk らの報告によると, IVUS では観察できない microcalcificationが豊 富な箘所の表面ではプラーク内応力が集中しやす いことを報告している13)。 MDCTなどの観察で は，石灰化スコアが高いものほど，心血管イベン トが起こりやすいとされている。このように石灰 化はプラークの vulnerabilityに対して，あると きは安定化させ，あるときは逆に不安定化させる 働きをしている可能性があり，その違いが何か は,さらなる研究が必要である。

\section{5. 脂質コア}

脂質コアが大きいプラークほぎ vulnerability が高いとされている，Richardson らは脂質コア の存在だけで, 表面の引つ張り応力が飛躍的に上 昇することを示している9 。ただし，筆者らによ る有限要素法によるシミュレーションによれば, 脂質コアの厚さは表面の線維性被膜での応力集中 に大きく影響しない4). しかし，その広がりが広 いほど, 線維性被膜内の多くの箇所に応力集中点 を生む。

\section{6. その他の病態}

プラーク内の出血が，まさしく火山噴火様のプ ラークの破裂をきたすという機序が示唆されてい る14). 不安定プラークではプラーク内で多くの新 生血管が描出されることが報告されている14).

Abela らは，プラーク内，とくに脂質コア内に しばしば認められる細長い菱形のコレステリン結 晶がプラーク表面の線維性被膜を穿通し，被膜破 裂のトリガーになっているのではないかという 興味深い病理学所見を報告した ${ }^{15)}$.わずかなプ ラーク表面の穴や亀裂が大きな破綻につながるこ とは十分考光られる。

陽性リモデリングの存在がプラークの vulnerability の高さを示すという報告がある16)。一つ は上記のような線維性被膜が菲薄化した脂質に富 んだプラークが存在していることが多いこと，も う一つはラプラスの法則（表面引つ張り忘力＝内 圧 $\times$ 内腔径/壁厚）により，プラークの厚さが厚 いほど応力は低くなるものの，陽性リモデリング により内腔径が維持されると, 引つ張り応力も高 いままに維持されることなどがその理由として考 えられる。

\section{プラク破綻の破壊力学的考察}

\section{1. プラーク破綻の力学的工学的側面}

破壞力学では，物質の破壊には，大きく脆性破 壞と延性破壊の 2 種類があるとされている．物 質が脆くも崩れ去るというのが脆性破壊，いった 几物質が伸びはじめ，伸びきってから破断すると いうのが延性破壞である。図 3 は，OCTで観察 したプラーク破綻部位の線維性被膜の断端である が，線維性被膜自体は，延性破壊を起こしている ような印象がある。しかし，内部の脂質コアは明 らかに脆性破壞を起こしているようにみえる.

図 4 はプラークにかかる力を整理したものであ る.この中で血圧由来の引つ張り応力がもつとも 大きい.プラーク破綻の driving forceも，この 引つ張り応力が主体であると考えられる，それに 比べてずり応力などはずっと小さな力である. 


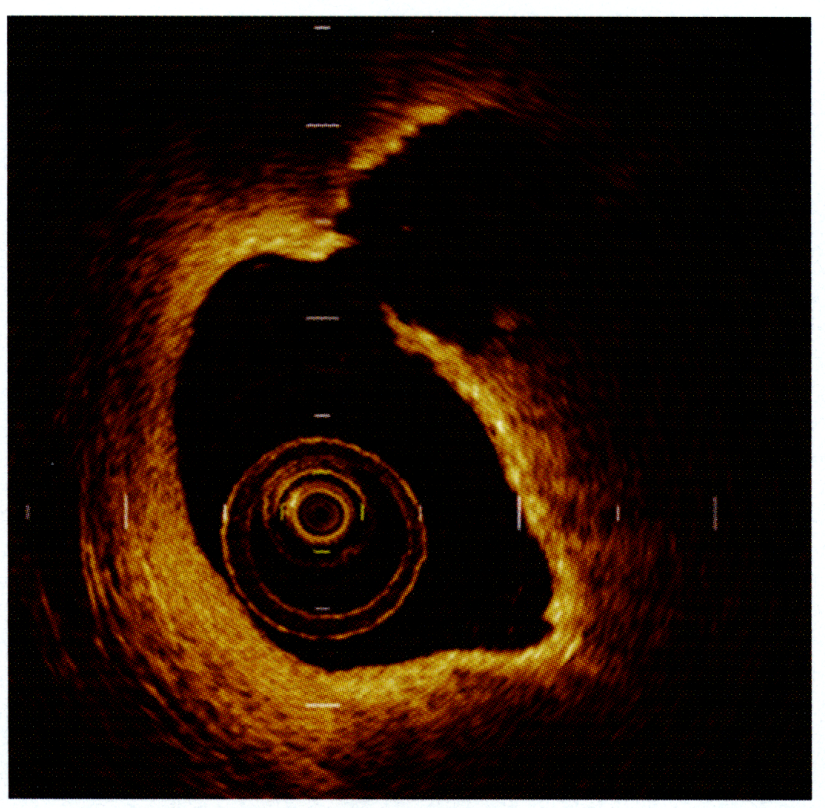

図 3 プラーク破綻の OCT 像

線維性被膜は引き延ばされて破断したように見え, 中の脂 質コアは脆くも崩れ去ったように見える.

\section{2. ずり応力について}

Fukumoto ならびに筆者らは, 血管内エコー画 像から内腔形状を抽出し，プラーク表面にかかる
ずり応力の分布をシミュレーション表示し, 破綻 との関係について検討した ${ }^{17)}$.

ずり応力は動脈硬化進展における重要な物理的 因子の一つであることがいわれている。ずり応力 は，流れによって血管の表面がずれる方向に働く 力に相当する．これは，血管内皮細胞を滑るよう に，あるいは変形させるように㗢く，その值 $(\tau)$ は,

$\tau=\rho \cdot d v / d x$

で表される。すなわち血流速度（v）を血管壁か らの距離 $(x)$ で微分したものに，血液の粘性度 （ $\rho ）$ を掛けることで算出される.

ずり応力の低い血管壁においては，プラークの 形成と血管リモデリングが生じやすいことが知ら れている18,19)。実際に，動脈硬化性プラークはし ばしば血管分岐部の外側や曲がった血管の小弯側 に存在し，このような部位では比較的ずり応力は 小さい. では，このずり応力とプラークの破綻と は，どう関係し合っているのであろうか.

血管内エコー法は in vivo で冠動脈プラークや 血管壁の二次元情報，さらには三次元の高画質断

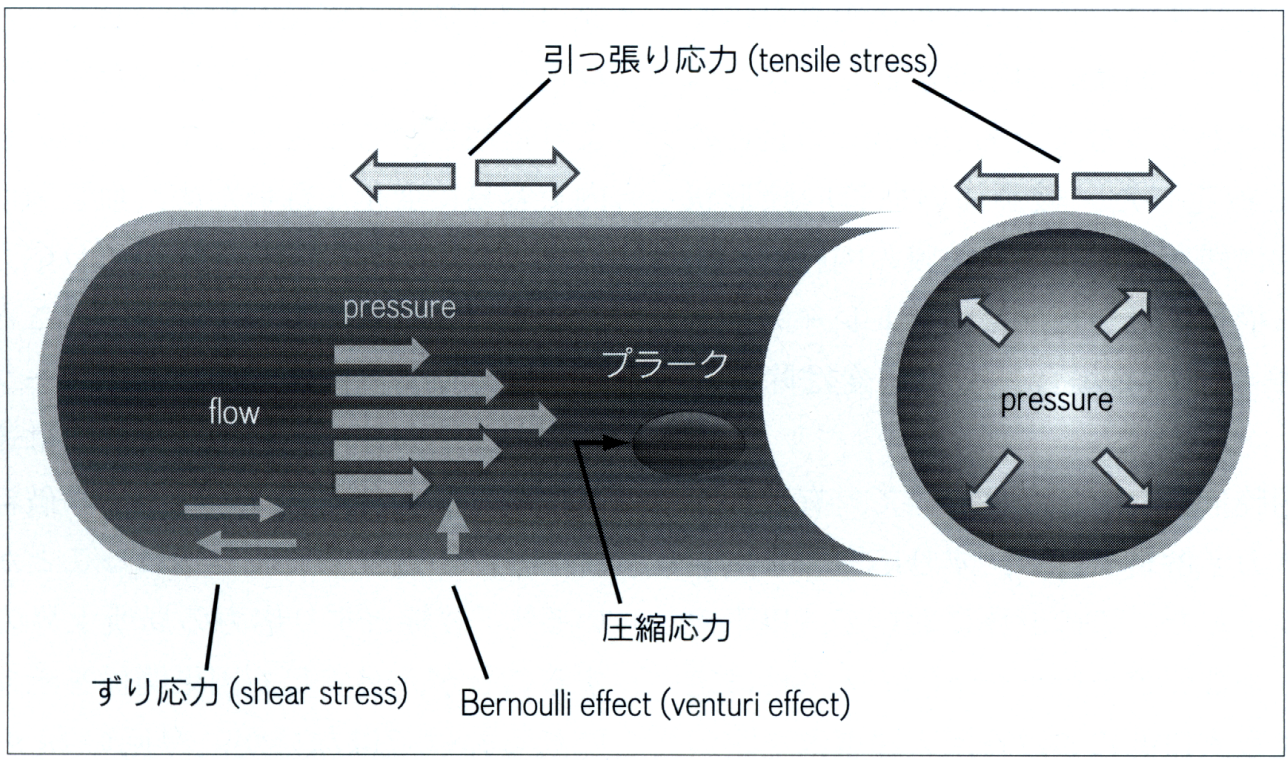

図 4 プラークにかかるカ

もっとも大きな力は血圧により生じる引つ張り応力である。このほか流れにより生まれる shear stress, Bernoulli effect による引き寄せ効果, 出っ張ったプラークには流机が当たるこ とにより生じる圧縮応力（引つ張り応力の逆）がかかる.これらの力が心周期に伴い強弱を 繰り返しながらプラークに常に加わっている. 
層像を得ることができるが，KramsらはIVUS と冠動脈造影を用いて，血管壁に沿った冠動脈内 のずり応力の三次元力ラー表示法を提唱した ${ }^{20)}$. この手法は高性能ではあるが，ずり応力の計算に 膨大な時間と複雑な技術を必要とするため，筆者 らはいくつかの市販アプリケーションを組み合わ せて，計算時間も少ないユーザーフレンドリーな プログラムで，ずり応力の分布をカラー表示化す るより簡便な手法を開発した。 そして，この新し いカラー表示プログラムと三次元 IVUSを用い て,ずり応力の分布と冠動脈プラーク破綻との関 係を検討した.

IVUS から得られた血管の三次元内腔情報は， まずコンピュータ流体力学解析のために必要な メッシュポリゴン構造体に変換した. 血管内腔の 空間的形状は, 短軸画像も参考にしながら, 三次 元 IVUS の長軸画像の内腔トレースを行って描 出した. 同じ手技を, IVUS カテーテルの中心を 軸として，10度ごとに長軸面を回転させながら 行った（計 36 本の長軸方向の血管内腔鋳型）.

IVUS カテーテルからの情報では, すべての側枝 の鋳型を描出することは困難であるため, まず分 岐部におけるそれぞれの側枝の血管径と分枝角度 を計測した，それから，主枝のずり応力計算に影 響が及ばないよう，側枝の内腔を計測した径と角 度を参考にそこから少なくとも $100 \mathrm{~mm}$ の長さの 側枝があると仮定した。破裂前の血管内腔形状 は，破裂部位に残存する線維性被膜の内腔断端を 外挿しながら構築を行つた. 被膜がトレースでき ないほざ変形している場合, その病変は除外し た.

次にこの内腔形状ファイルについて, 有限要素 法による流体力学解析を行い, ずり灾力の三次元 分布を計算表示した. この計算において, 以下の ようなさまざまな仮定を行った。 (1)流入条件は定 常層流, (2)血管入口部における流入速度は一定の $30 \mathrm{~cm} / \mathrm{sec}$, (3)流出口は圧抵抗なし, (4)血管壁に スリップなしままた，動脈壁には弾性がなく，血 液は非圧縮で均一とし, 密度 $1,050 \mathrm{~kg} / \mathrm{m}^{3}$, 粘性 度0.003 Pas のニュートン物性と仮定した。観察
した血管に分岐がある場合，それぞれの分枝に向 かう流量は, 分枝入口部の断面積の值にようて分 割した。

このカラー表示により, ずり応力が局所的に高 くなっている部位が明らかに認められた。代表的 な症例を図 5 に示す。なお壁伸展血圧の局所分布 については，血管壁に沿うように長軸方向に段階 的な変化が観察され泣したが, 局所的な集中像は 認められなかつた。このずり応力の局所的上昇部 位はプラークの破裂部位と明らかに一致していた $(\mathrm{Kappa}=0.79) . こ の$ 結果はプラーク表面上のず り応力の局所的な上昇が冠動脈プラーク破綻に関 与していることをはじめてin vivoで示したもの である．ただずり応力の計算のために多くの仮定 を用いており，計算して求めたずり応力の絶対值 に対する信頼度は低いかもしれないが，プラーク 表面に加わるずり応力の「分布」のカラー表示法 がプラークの破綻部位を予測する有用な手段とな りうる可能性を示唆している.

ずり応力が低いところほどプラークが形成され やすいことが報告されているにもかかわらず，で はなぜずり応力の局所上昇が破綻点と関係するの だろうか.ずり応力の絶対值はプラーク内応力に 比べれば破綻に直接かかる力としては取るに足ら ないくらい小さい，先に述べたずり応力の定義式 より推察されることとして, 血液の粘性度は血管 内で容易に変化しないため, 血管断面の短軸方向 に沿った流速の段階的変化がずり応力の值を決定 するもっとも重要な因子だということである．た とえば，血管内腔に突出したプラークの盛り上が りがあると, 速度勾配は理論的には遠位側よりも 近位側で高くなる．実際プラーク破綻がしばしば プラークの近位側で観察されることが報告されて (る8). 破綻とずり応力の局所上昇の場所が一致 することが，必ずしも因果関係を示す完全な証拠 になるわけではないが, 今回の in vivoでの結果 から, 高いずり応力をもったプラークの部分に破 裂が起こりやすいということは十分示晙されう る. 前述のように頸動脈プラークにおけるマクロ ファージ集簇度に関する研究によれば，マクロ 


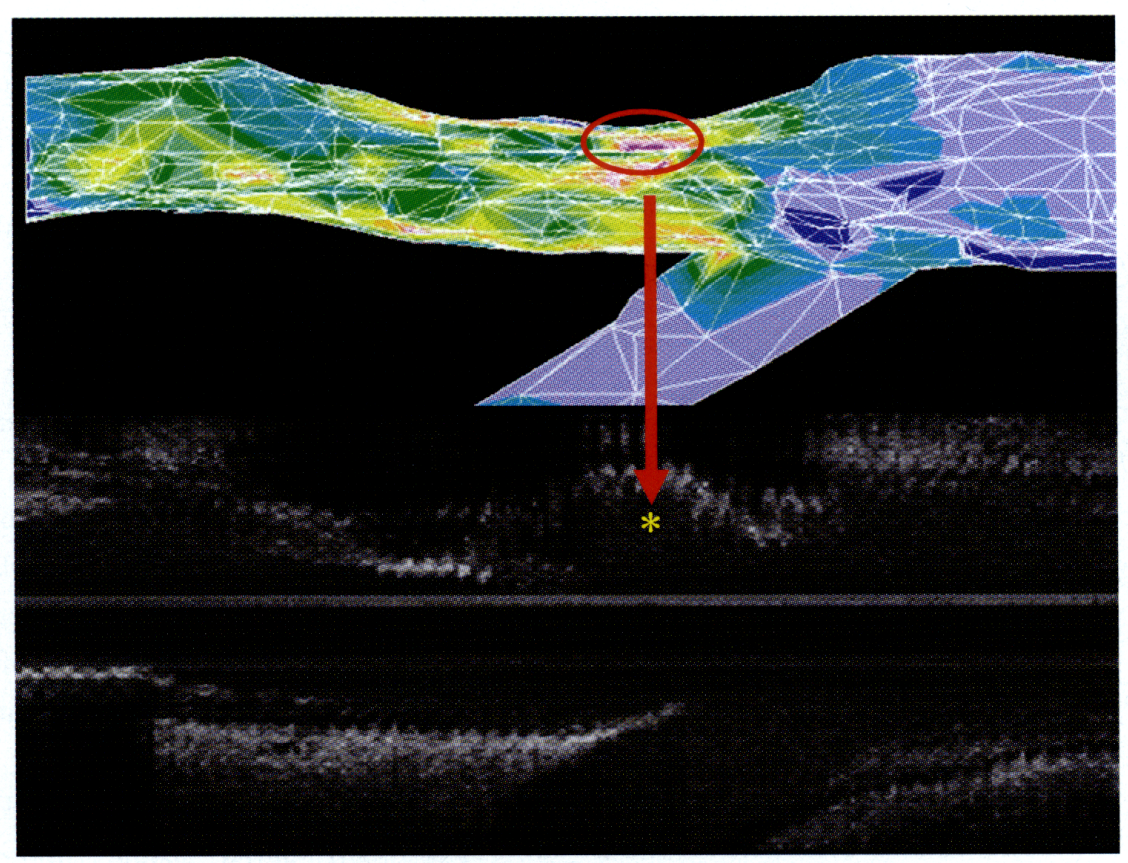

図 5 ずり応力の集中点とプラーク破綻点が一致している例 上図は IVUS を用いて有限要素法によるずり応力のカラーマッピングを行った もの.ずり応力の局所集中部（赤色部）が下の破綻部に一致していることがわ かる.

(文献17より引用)

ファージは動脈硬化病変の下流よりも上流におい て多く認められやすい8).さらに, Gertzらによる in vivo 研究で, 動脈が狭窄している部分でみら れた壁ずり応力の増大は，内皮傷害とそれに続く 露出した内皮下組織に対する血小板凝集と血栓形 成を引き起こしうることが報告されている21).

このようにずり応力イメージングは, vulnerable plaque に特徵的な組織性状や構造物を描出す るという観点ではなく，プラーク破綻とリンクし ている何らかの現象ないしトリガーをあらかじめ 見出すという「プラーク破綻の新たな予測法」と して期待されるのである.

\section{3. プラーク破綻の進展過程}

上記の種々の要因を経て，プラーク表面のある 箇所にまずわずかな亀裂が生じるものと考えられ る。 そのわずかな亀裂が生じると, 材料力学的に 特別な状況が起こる. すなわち，とくにその亀裂 の中で曲率半径が小さな部分に大きな応力が集中 するようになる，そしてそのわずかな亀裂が一気 に大きな破断を生む. 紙をそのまま引つ張っても
なかなか破れないが，端に小さな破れ目を入れて おくと一気に破裂することを考えれば，このこと が直感的に理解できよう.

そしてひとたび線維性被膜の破断がはじまる と, その亀裂は長軸方向になるべく進むものと推 察される，というのも，血管のような薄肉円筒モ デルでは材料力学的に長軸方向の引つ張り応力よ り, 円周方向の引つ張り応力のほうが 2 倍強いか らである（円周方向のほうがより引つ張られるた めに亀裂が長軸方向に進みやすい)。しかし，亀 裂はしばしばギザギザとした形をしている，とい うのは, 亀裂の進行は各時点でもっとも脆弱な箇 所を選んで進んでいくからである.

\section{4. スパスムの関与}

プラークの破綻には血管のスパスムが関与して いるのかどうかが議論となっている. スパスムだ けで心筋梗塞が発症するのはまれであるとの見解 がある. スパスム誘発試験で心筋梗塞発症が起こ ることがまれであることもその根拠になってい る.しかし一方で一度のスパスムではなく, 頻回 
に繰り返すスパスムが関与しているとの反論があ る. スパスムは図4でいえば引つ張り応力とは逆 方向に力を働かせているので，破綻にはむしろ拮 抗的に㗢くようにみえる。しか，スパスムの際 にはプラークの収縮は少なく，健常壁が攣縮する ために, プラークの肩領域はむしろ引つ張り応力 が集中する．またスパスムは長軸方向に均等では ないので，ある場所は強く，ある場所は弱い，と いうことになりその間に歪多生じやすくなる. ときに，プラークの破綻部位が長軸方向ではな く，横に割れてみえることがあり，このような現 象が関与しているかもしれない.

以上のようにプラークの破綻の開始と進展にさ まざまな機序が介在していることがわかる.

\section{血栓形成}

プラークの破綻にしろ，びらんにしろ，内出血 やそれ以外の機序にしろ, ACSの発症には最終 的に血栓形成が大きく関与する。血栓が小さけ ればプラークの破綻は無症候性に終わるため, ACS が発症するためには血栓が十分大きなもの に発達することが必要である，そのためには，血 栓を起こしやすい血液凝固能や血小板凝集能の異 常克進 (vulnerable blood), 逆に線溶系の局所的 ないし全身的抑制，組織因子儤露など血栓惹起性 の異常艺進，プラーク破綻の形や程度，あるいは その部位の狭窄による血流遅滞化などのレオロ ジ一的環境条件など，多くの因子が明らかにされ つつある。これらの因子がごの程度関与している かもまた，ACSの進展の大きな決定因子である. 個別には以前より多くの研究がなされているが, 統合的にACS の進展機序としてまとめられるに はいたっていない.プラーク破裂やそれに伴う血 栓形成の動物モデルが最近ようゃくできつつあ り，この分野での正確な機序解明が待たれるとこ ろである。

1) Rioufol G, Finet G, Ginon I et al: Multiple atheros- clerotic plaque rupture in acute coronary syndrome: a three-vessel intravascular ultrasound study. Circulation 2002; 106: 804-808

2) Naghavi M, Libby P, Falk $E$ et al: From vulnerable plaque to vulnerable patient: a call for new definitions and risk assessment strategies: Part 1. Circulation 2003; 108: 1664-1672

3) Virmani R, Burke AP, Farb A et al: Pathology of the vulnerable plaque. J Am Coll Cardiol 2006; 47: C13C18

4) Imoto K, Hiro $T$, Fujii $T$ et al: Longitudinal structural determinants of atherosclerotic plaque vulnerability: a computational analysis of stress distribution using vessel models and three-dimensional intravascular ultrasound imaging. J Am Coll Cardiol 2005; 46: 15071515

5) Tanaka A, Imanishi $T$, Kitabata $\mathrm{H}$ et al: Morphology of exertion-triggered plaque rupture in patients with acute coronary syndrome: an optical coherence tomography study. Circulation 2008; 118: 2368-2373

6) Asakura M, Ueda Y, Yamaguchi $O$ et al: Extensive development of vulnerable plaques as a pan-coronary process in patients with myocardial infarction: an angioscopic study. J Am Coll Cardiol 2001; 37: 12841288

7) Pasterkamp G, Schoneveld AH, van der Wal AC et al: Inflammation of the atherosclerotic cap and shoulder of the plaque is a common and locally observed feature in unruptured plaques of femoral and coronary arteries. Arterioscler Thromb Vasc Biol 1999; 19: 54-58

8) Dirksen MT, van der Wal AC, van den Berg FM et al: Distribution of inflammatory cells in atherosclerotic plaques relates to the direction of flow. Circulation 1998; 98: 2000-2003

9) Richardson PD, Davies MJ, Born GV: Influence of plaque configuration and stress distribution on fissuring of coronary atherosclerotic plaques. Lancet 1989; 2: 941-944

10) Maehara A, Mintz GS, Bui AB et al: Morphologic and angiographic features of coronary plaque rupture detected by intravascular ultrasound. $\mathrm{J}$ Am Coll Cardiol 2002; 40: 904-910

11) Ehara S, Kobayashi $Y$, Yoshimura $M$ et al: Spotty calcification typifies the culprit plaque in patients with acute myocardial infarction: an intravascular ultrasound study. Circulation 2004; 110: 3424-3429

12) Virmani R, Burke AP, Farb A et al: Pathology of the vulnerable plaque. J Am Coll Cardiol 2006; 47: C13C18 
13) Vengrenyuk $Y$, Cardoso L, Weinbaum S: Micro-CT based analysis of a new paradigm for vulnerable plaque rupture: cellular microcalcifications in fibrous caps. Mol Cell Biomech 2008; 5: 37-47

14) Virmani R, Kolodgie FD, Burke AP et al: Atherosclerotic plaque progression and vulnerability to rupture: angiogenesis as a source of intraplaque hemorrhage. Arterioscler Thromb Vasc Biol 2005; 25: 20542061

15) Abela GS, Aziz K: Cholesterol crystals cause mechanical damage to biological membranes: a proposed mechanism of plaque rupture and erosion leading to arterial thrombosis. Clin Cardiol 2005; 28: 413-420

16) Schoenhagen $P$, Ziada KM, Kapadia SR et al: Extent and direction of arterial remodeling in stable versus unstable coronary syndromes: an intravascular ultrasound study. Circulation 2001; 104: 653-657

17) Fukumoto $Y$, Hiro $T$, Fujii $T$ et al: Localized elevation of shear stress is related to coronary plaque rupture: a three-dimensional intravascular ultrasound study with in vivo color mapping of shear stress distribution. J Am Coll Cardiol 2008; 51: 645-650

18) Asakura $T$, Karino $T$ : Flow patterns and spatial distribution of atherosclerotic lesions in human coronary arteries. Circ Res 1990; 66: 1045-1066

19) $\mathrm{Ku} \mathrm{DN}$, Giddens DP, Zarins CK et al: Pulsatile flow and atherosclerosis in the human carotid bifurcation. Positive correlation between plaque location and low oscillating shear stress. Arteriosclerosis 1985; 5: 293-302

20) Krams R, Wentzel JJ, Oomen JA et al: Evaluation of endothelial shear stress and $3 \mathrm{D}$ geometry as factors determining the development of atherosclerosis and remodeling in human coronary arteries in vivo: combining $3 \mathrm{D}$ reconstruction from angiography and IVUS (ANGUS) with computational fluid dynamics. Arterioscler Thromb Vasc Biol 1997; 17: 2061-2065

21) Gertz SD, Roberts WC: Hemodynamic shear force in rupture of coronary arterial atherosclerotic plaques. Am J Cardiol 1990; 66: 1368-1372

\section{用圄觕说}

\section{CETP 阻害薬}

CETP とは，コレステロールエステル転送 蛋白の略である。この蛋白を阻害して高比重 リポ蛋白（HDL）コレステロールを増加さ せる薬剤（CETP 阻害薬）の開発が盛んに 行われている，CETPは，HDLからコレス テロールエステルを引き抜き，低比重リポ蛋 白（LDL）や超低比重りポ蛋白（VLDL）に 転送する作用がある。したがって，CETP を阻害すると，HDLコレステロールが増 え，LDLコレステロールを減らすことが期 待できる.

まず，CETP 阻害薬としてトルセトラピ ブが開発され，治験結果が発表された。 トル セトラピブによって，HDL コレステロール
は増加したが，アルドステロン産生増加と考 えられる血圧の上昇を招き，開発が中止され た.しかし，2010年11月，次の CETP 阻害薬 アナセトラピブの第吕相臨床試験 DEFINE 試験の結果が明らかにされた。今回の安全性 を確認した試験では，トルセトラピブでみら れた血圧上昇や副腎への悪影響などはなく， 強力な脂質改善効果（投与 24 週後に LDL コ レステロールは半減, HDL コレステロール は倍増）を認めた. 今後, スタチンに次ぐ, 次世代の有効な脂質管理を目指した新薬とし て期待されている.

（福岡大学医学部心臟・血管内科学

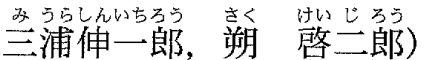

